\title{
The Construction of an Ontology-Based Knowledge Management Model for Departure Procedures
}

\author{
Kuo-Wei Su1*, Chun-Hung Yang2, Po-Hsin Huang² \\ ${ }^{1}$ Department of Information Management, National Kaohsiung First University of Science and Technology, \\ Taiwan \\ ${ }^{2}$ Department of Industrial Engineering and Engineering Management, National Tsing Hua University, Taiwan \\ Email: "kwsu@nkfust.edu.tw
}

Received 18 April 2016; accepted 24 June 2016; published 27 June 2016

Copyright (C) 2016 by authors and Scientific Research Publishing Inc.

This work is licensed under the Creative Commons Attribution International License (CC BY). http://creativecommons.org/licenses/by/4.0/

(c) (i) Open Access

\begin{abstract}
With increased global economic development, the air traffic volume (including passengers and parcels) increases every year. Thus, the business-related load on air traffic controllers becomes heavier, which influences their need for frequent learning and training opportunities. Therefore, the only solution is to enhance the performance of the training for the air traffic controllers (ATCs) and to build uniform training procedures and standardized training content, which constitute a shared framework with ontology knowledge. Taking departure operation control processes as an example, the research analyzes an aviation organization framework, with information communication procedures and relevant knowledge assets from the viewpoint of departure processes, to explore a knowledge management model of aviation control. This research studies how explicit knowledge is transformed by CommonKADS methodology using the CommonKADS sheet, and the Unified Modeling Language (UML) graph presentation and ontology model are discussed in this research. This analysis procedure can be applied to the systematic analysis and establishment of similar business-based information systems, allowing this research result to be further shared in different industries.
\end{abstract}

\section{Keywords}

Air Traffic Controllers (ATCs), Departure Procedure, Ontology Knowledge, CommonKADS Methodology

\footnotetext{
${ }^{*}$ Corresponding author.
}

How to cite this paper: Su, K.-W., Yang, C.-H. and Huang, P.-H. (2016) The Construction of an Ontology-Based Knowledge Management Model for Departure Procedures. Advances in Aerospace Science and Technology, 1, 32-47. 


\section{Introduction}

The aviation operation is a large and complicated man-machine system, in which all crew members need to master high-level knowledge and skills and cooperate for the reduction of human error. The International Civil Aviation Organization (ICAO) is based on a SHELL model [1], which has its name derived from the initial letters of its components: Software, Hardware, Environment and Liveware. In other words, because SHELL is people-centered, it encompasses the relational properties between other people, hardware and software, as well as environmental interfaces. The associated properties include situation identification, operational knowledge and decision-making skills [2]. The ICAO cannot reach the ideal status of personal property completely integrating into the environment. However, through regulating the learning process and the training content, the ICAO can lower the difference between operation decisions made by different people and can reduce errors that cause civil aviation accidents and other consequential events, among which human errors play a significant role [2] [3]. For human factor (HF) actions, implementation of frequent learning and training provides a feasible solution.

With increased global economic development, the air traffic volume (including passengers and parcels) increases every year. Thus, the business-related load on air traffic controllers (ATCs) becomes heavier, which influences their need for frequent learning and training opportunities [4]. Therefore, the only solution is to enhance the performance of the training for the ATCs [5] and to build uniform training procedures and standardized training content, which constitute a shared framework with ontology knowledge. This strategy allows the ATCs to obtain relevant knowledge and information based on their own needs and to relieve the decision-making inconsistencies that occur during air traffic operations [6]. An air traffic knowledge control system is very important for safety and efficiency. For pilots and ATCs, personal knowledge remains the main resource for making decisions. A newly integrated operating system for flight control mechanisms can only achieve real-time sharing and consultation between ATCs during flight operations. To reduce operational error possibilities, it has been clearly demonstrated that a target working scope, improved design and organizational flow can be achieved $[7]$.

Furthermore, due to the complex process of control operations and the frequent updating of air traffic management programs by the ICAO, it is of great importance to boost the established resources of knowledge management systems by information technology to rapidly reflect the work standards of the ICAO and to develop a control operation knowledge management mode. In this research, this study proposes to apply the CommonKADS knowledge engineering model as the development tool for the system. Taking the scope of the "departure control operation” for discussion, professional knowledge will be analyzed and modularized, and a uniform language will be adopted so that relevant knowledge can be schematized to derive an ontology knowledge. The analysis scope covers descriptions of operational background environments, expert operation decisions of knowledge extraction and practical work experience of senior working personnel. The ontology knowledge will be built for air traffic control personnel, and then a Protégé humanized interface will be adopted to establish a knowledge management model of a departure control operation.

Taking departure operation control processes as an example, the research analyze an aviation organizational framework, with information communication procedures and relevant knowledge assets from the viewpoint of departure processes, to explore a knowledge management model of aviation control. The objectives of this article are as follows:

1) Based on the ontology concept, we establish navigation management knowledge relations.

2) Organize relevant knowledge in a systematic way to reduce the time needed for operations work.

3) Establish a knowledge system model to assist an aviation control unit in importing a knowledge management system.

\section{Literature Review}

\subsection{Control Operation and Human Error}

The purpose of the control operation is to provide the pilot with environmental and other relevant information and to coordinate aircraft activities in the sky and on the ground to ensure a safe flight for the pilot, passengers and cargo. Each control level is classified into different aerial control areas, and the operation contents of each level differ according to different seats. The control personnel are each responsible only for the work of an indi- 
vidual seat.

Except for control personnel in the control tower, other aviation management personnel guide aircraft to accomplish flight operations safely and efficiently using information provided by radar such as height, speed, weather and relevant aviation information. Control personnel must evaluate a large amount of information and must rapidly make decisions in a short time period with a very high operating standard; furthermore, control personnel must be very familiar with control operations procedures and with communications procedures when providing control services. Control personnel should also immediately understand and respond to any condition. There are many precautions in aviation control services, including maintaining a distance between aircraft and knowing the descent rate of different aircraft models to maintain that distance. The features of control operations in airport control towers include controlling aircraft by making use of visual and airport search radar and issuing entrance and departure permissions to aircraft to ensure safe, rapid and orderly flight activities of aircraft. Boeing Airplane Company (2005) [8] has calculated the accident rate of aircraft in each stage, the accident rate is highest when aircraft take off (17\%) and land (52\%), totaling 69\%.

According to the American Flight Safety Foundation, 85\% of flight accidents were due to human factors; a survey by the ICAO also indicated that accidents caused by human factors amount to $60 \%-80 \%$ of the total. As gathered in this research, among the errors of control personnel in the departure and entrance operations process, insufficient distance, operating against instructions, judgment mistakes, carelessness and incorrect altitude information account for the highest error rates. These shows that control operations personnel take the greatest responsibility and have the largest error rate in the departure and entrance stages. According to the expert interview, through the more training and research in the aviation management personnel are able to solve problems caused by such human factors and will be able to reduce error occurrences.

\subsection{Knowledge Management and CommonKADS}

Wilson and Asay (1999) [9] defined knowledge management as providing rapid access to expertise throughout entire systems as needed to enhance individual learning and performance. Other studies have investigated learning mechanisms throughout organizations and investigated the development of dynamic capabilities, which are defined as re-utilized activities that are directed to the development and adaptation of operating routines [10].

Knowledge management consists of four sets of socially enacted knowledge processes, namely: 1) knowledge creation, 2) knowledge organization and storage/retrieval, 3) knowledge transfer, and 4) knowledge application [11]-[13].

Introduced by Akkermans et al. (1999) [14], CommonKADS is the leading methodology for supporting structured knowledge engineering. CommonKADS was gradually developed and has been validated by many companies and universities in the context of their programs, which assist with analyzing enterprise environments, extracting expert knowledge and experience, and computerizing these processes. The CommonKADS capability for analyzing, developing and storing knowledge is used by many researchers and scholars at home and abroad to study the enterprise processes and professional knowledge models in various fields. CommonKADS is a very useful methodology from the perspective of externalization, namely for transforming tacit knowledge into explicit knowledge, which supports the development of knowledge systems that are valuable in selected parts of the business process.

\subsection{Ontology}

Ontology is not a new terminology for computer science, although it appear earlier in philosophic fields and was used to define and search universal questions, such as the composition and architecture of the world. Ontology can be applied to a specific domain for describing the taxonomy of concepts for tasks or the semantic interpretation of knowledge. Currently, the notion of an ontology is also becoming visible in fields such as intelligent information integration, information retrieval, knowledge management, web standards, online databases, and multi-agent systems [15]. In the computer realm, an ontology is often referred to in the fields of expert systems and artificial intelligence and is used to specify particular domain knowledge [16] by describing different types of entities in the world and how they are related in a systematic way [17] to achieve the purpose of knowledge representation and sharing [18]. Ontology is a hierarchically structured set of terms to describe a domain that can be used as a skeletal foundation for a knowledge base [19].

Therefore, an ontology can not only classify learning resources but can also accumulate domain knowledge 
and enhance the usability of learning resources, which is significant for enabling educators to build up a student's expertise from educational experiences. The inclusion of an ontology also aims to strengthen a student's search ability in the domain knowledge by providing suggestions to learners, promoting learning interest and eliminating barriers to learning. Web ontology language $(\mathrm{OWL})$ is a language designed to meet the requirements of the Internet for an ontology, presenting abstract concepts in a structured fashion. The bases of OWL are extensible markup language (XML) and resource description framework (RDF); therefore, OWL has XML's advantage in formatting and RDF's advantage in resource descriptions [20].

An ontology construction tool is implemented to build ontology concepts, and then, the ontology is evaluated. In recent years, tools and systems for constructing ontology metadata have been developed, for example, Protégé by Stanford Medical Informatics [21]. This tool is an open source, standalone application with an extensible architecture. The core of this environment is the ontology editor, which holds a library of plugins that add more functionality to the environment [22]. According to the referenced research, this study would use Protégé to develop the Knowledge Management Model for Departure Procedures.

Further, the Unified Modeling Language (UML) is used to specify, visualize, modify, construct and document the artifacts of an object-oriented software intensive system under development [23]. UML can be used with all processes throughout the software development life cycle and across different implementation technologies. With high performance, UML can order, construct and record the output of software-based systems in a visualized way, having the characteristics of specifying, visualizing, documenting, and constructing. Its composite elements include Event Relation and Graph, the graphic expression of a series of elements by a combination of points (events) and lines (relations). In this research, this study uses the activity diagram, which shows the overall flow of control.

\section{Research Methodology}

Before you begin to format your paper, first write and save the content as a separate text file. Keep your text and graphic files separate until after the text has been formatted and styled. Do not use hard tabs, and limit use of hard returns to only one return at the end of a paragraph. Do not add any kind of pagination anywhere in the paper. Do not number text heads - the template will do that for you.

Finally, complete content and organizational editing before formatting. Please take note of the following items when proofreading spelling and grammar:

\subsection{Departure Procedures}

Departure procedures mainly provide for the taking off of the aircrafts. Based on the difference between the service scope and the operational pattern, the service of air traffic control can be divided into three categories, namely, airport control, area control and approach control. If classified based on the working property and content, it is composed of the following types: ground control and clearance delivery. A brief introduction to the service items involved in the departure procedure is as follows:

\section{Organization Introduction}

1) Terminal Approach Control: The terminal approach control is responsible for providing the service of approach isolation and control during departure, climbing, approach and landing within the terminal area.

2) Area Control and Route Control: The area control and route control is responsible for directing all flight aircrafts within the Taipei Flight Information Region (FIR) to maintain the standard safe isolation with each other using wireless devices and radar. There are six control areas in total.

3) Aerodrome Control Tower: The aerodrome control tower is responsible for providing the services of pushing back, taxiing, taking off, landing and going-around to the aircraft. Generally, this responsibility is limited to aircraft within a certain oriented scope, taking the airport as the center and 5 or 7 miles as a diameter, or a vertical scope lower than 3000 feet, including the airspace above the airport and the ground operational zone.

\section{Departure Isolation Procedure}

1) GroundControl: The ground control is mainly responsible for the taxiing of the aircraft, the moving of the vehicles on the ground, the releasing of the departure data, the weather reports and the airport information. Generally, ground control is also responsible for controlling the taxi way and the available runways.

2) Aircraft: Before taxiing, the aircraft must accept isolation service that is coordinated by the following control sectors, namely Ground Control, Clearance Delivery, Tower and Departure. 
3) Clearance Delivery: Clearance delivery is responsible for delivering permission for the flight and choosing the departure procedure, route and destination, as well as the cruising height for the flight.

4) Tower: Tower is responsible for controlling departure, landing and all aircraft on the runway or for executing the related procedures under the visual flight environment. Tower is responsible for constant visual monitoring within the airport and the surrounding airspace.

Departure Control: Departure is responsible for controlling all aircraft taking off based on the Instrument Flight Rules within the control scope, which includes reporting the wind direction and speed to the aircraft on the runway for flight permission.

\subsection{Expert Interview}

In view of the relevant information, the ATC staff in the Domestic Resources section does not provide much information. This study through expert interviews and documentation of information, builds the existing operating procedures and information on the departure procedures for air traffic control. An interview with an expert involves a bi-directional communication processes, ranging from obtaining responses to obtaining data. Use of expert interviews allows the acquisition of more valuable information compared to telephone surveys or mail surveys, and more detailed and more in-depth information is obtained, especially from an interviewer who has the ability to improve the quality of the information.

Considering the operation and taking into account the familiarity and expertise of the expert, the choice of experts was made according to qualifications and job familiarity. In this study, based on this principle, this study chose the retired head of the Civil Aviation Authority Air Training Center as the expert for the interview. This studyincludes interviews with the head of the Department of Education for the Civil Aviation Authority, who has been in air traffic control for many years and worked for a long time in the civil aviation personnel training institute; in addition, he has teaching experience as a team leader. The study also collected information by visiting and participating in aviation training center conferences to consolidate the current status and issues of aviation. Finally, this study could view the empirical results from different angles and are able to collect more valuable practical experience and ideas.

\subsection{Knowledge-Based Engineering Method}

To achieve the goal of reducing the probability of error occurrences during control operations, the improvement of operational designs and organizational flow can be realized [6]. However, prior to making any improvement, systematic detection must use the working analysis method first. This study uses the CommonKADS knowledge project and control methodology proposed by Akkermans et al. (1999) [14], which is mainly composed of 6 analysis models and can be divided into three categories for analyzing organizational environments, namely, the Context Model, Concept Model and Artifact Model. From extracting the expertise knowledge and experience during computerization, CommonKADS combines uniform language tools, which are a set of widely-used knowledge project and control methodologies. In many domestic and foreign studies, scholars make use of CommomKADS to expedite the study of professional knowledge from many different fields, which works well, especially with externalization [6].

The flow chart of this study is shown in Figure 1. Through the analysis flow formed by the organizational model, working model and agent model, the framework is used to discuss possible influences produced by the organizational environmental layer. The framework first starts from the tool table OM-1 to OM-5 provided by the organizational model to identify the degree of knowledge density within the operational procedure and to find possible solutions, to work out distribution schemes for distributing the knowledge, to evaluate knowledge assets, to decompose the development procedure and to confirm the feasibility of the proposed solutions from the perspective of execution, technology and the project, all of which are used to determine whether the analysis should be continued.

Next, a working model will be used to analyze the internal work flow of an organization, including the goals, steps to be executed, resource equipment aids, working knowledge needed, skills needed, and any limits on implementation times. This analysis is followed by the agent model. The analysis takes detailed records of everyone involved in the working flow and collects information about the department, responsibilities, message transmission and applied knowledge resources. Through the hierarchical analysis of each phase, this study could better evaluate the situation within the organization, which can help us to analyze the interests of different layers 


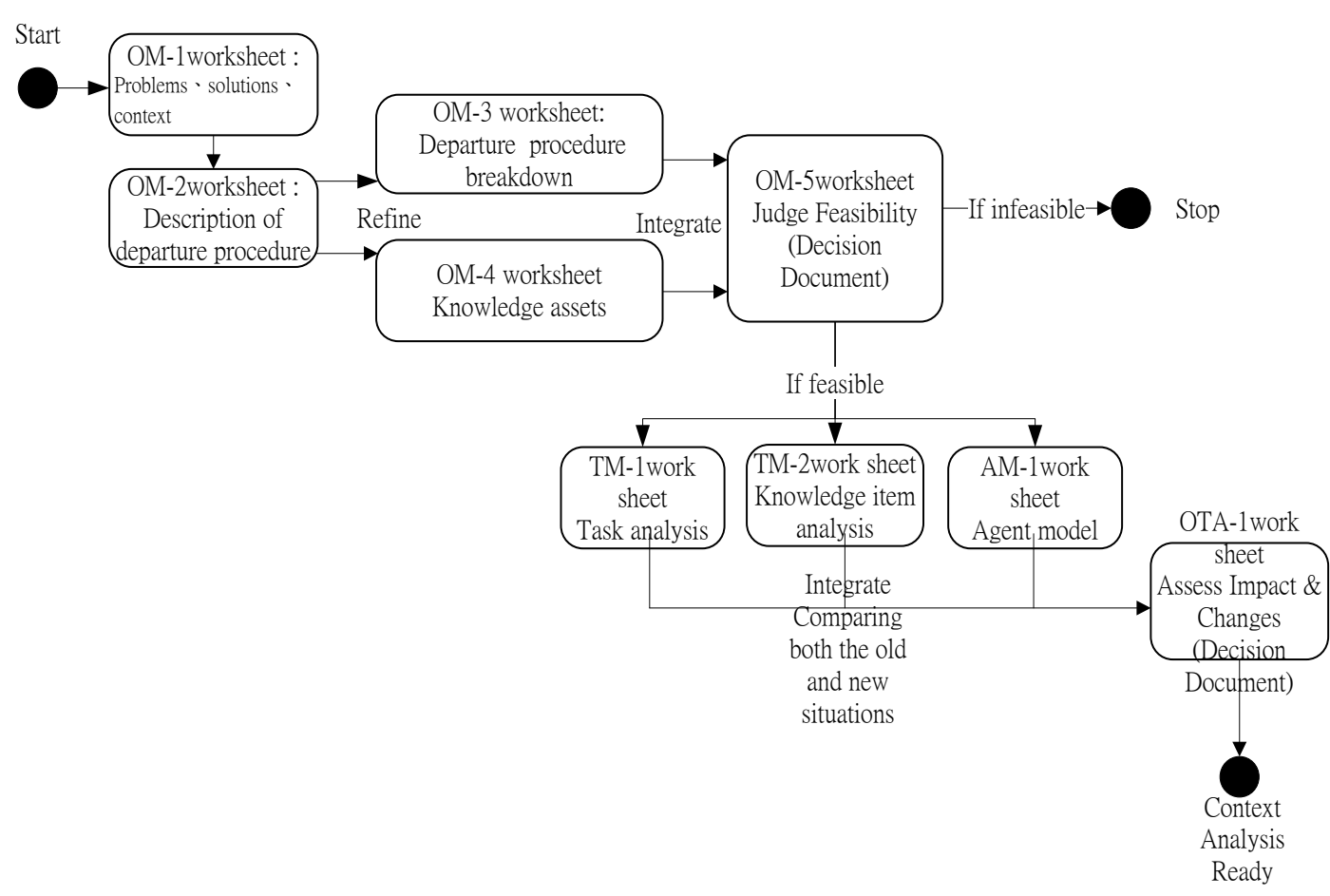

Figure 1. Flowchart of domain knowledge (Booch et al., 1998) [24].

and to make evaluations of the costs and risks. Furthermore, the analysis can help to improve shortcomings and to propose solutions, which can be taken as a reference by others.

\section{Development of Knowledge System Model}

This section establishes the model provided by the domain expert on the CommonKADS analysis sheet by following the study framework, thus analyzing the complex operation procedure of departure control, as well as the management model of departure controlling operation knowledge through a structured analysis of the professional knowledge and by expressing the active framework of departure control with a UML. The CommonKADS model suite is composed of a total of six models, as listed: Organization Model (OM), Task Model (TM), Agent Model (AM), Knowledge Model (KM), and Communications Model (CM).OM and CM are taken as examples in this article.

\subsection{Construction of Organization Model (OM)}

It is necessary to make a brief description of the organizations, operating principles, objects and external factors, through interviewing, brain storming and developing insights at the conference institute. Proposed methods can be discussed with the training institute of civil aviation, then lists can be made of the key elements of the problems that are identified. It is required to list possible solutions for the problems and opportunities that have been found. See Table 1, which shows the organization model working sheet OM-1.

\section{Working Sheet of Problems and Opportunities OM-1}

\section{Multi-faced Opinion Working Table OM-2}

The effects of problems must be analyzed in six parts, including the related department structure, the resource culture and power, and the enterprise organization specific to the problems and opportunities described in OM-1. Table 2 shows a multi-faces opinion working sheet.

\section{Procedure decomposition worksheet $\mathrm{OM}-3$}

It is required to complete the work in each procedure separately according to the working procedures of OM-2 and to decompose the knowledge assets applied in the work decomposition combined with evaluating the significance of the knowledge. Table 3 shows a worksheet for procedure decomposition. 
Table 1. Worksheet OM-1.

\begin{tabular}{|c|c|}
\hline \multicolumn{2}{|c|}{$\begin{array}{l}\text { Organization Model } \\
\text { Problems and Opportunities Worksheet OM-1 }\end{array}$} \\
\hline $\begin{array}{l}\text { Problems and } \\
\text { opportunities }\end{array}$ & $\begin{array}{l}\text { Problems: } \\
\text { 1. Due to the complex departure controlling operation process and the large number of items to check and copy, } \\
\text { the response time shall be fast and the risk is high, accordingly. } \\
\text { 2. The process of cultivating personnel is difficult, and the knowledge and experiences stored in the experts } \\
\text { consequently cannot be inherited nor the knowledge reused. } \\
\text { 3. The working load is heavy because the response of the control operation should be fast. } \\
\text { 4. The teaching documents and operation process shall be modified based on the updating of the International } \\
\text { ICAO control operation process. } \\
\text { 5. The online learning resources of the civil aviation institute are insufficient. } \\
\text { Opportunities: } \\
\text { 1. Establish a management model of control operations knowledge to reflect the departure controlling operation } \\
\text { and the changes in regulations of international organizations in real time. } \\
\text { 2. Re-establish an information system to cope with the complex control operation process. }\end{array}$ \\
\hline $\begin{array}{l}\text { Organizational } \\
\text { context as the PMO } \\
\text { point of view }\end{array}$ & $\begin{array}{l}\text { - Create a new situation of management by applying information technology. } \\
\text { - } \text { svaluate the knowledge of the control operation field to promote an understanding of the process and to seek } \\
\text { - Make the real-time change of control operations possible, thus facilitating the use of electronic systems. } \\
\text { 2. External factors: } \\
\text { - Enhance the operating efficiency to improve the flight safety. } \\
\text { - Reduce the rate of violating the relevant regulations and causing major damage. } \\
\text { 3. Policy: } \\
\text { - Provide, integrate and complete educational training. }\end{array}$ \\
\hline Solutions & $\begin{array}{l}\text { 1. Make detailed records of the operation process; create systematic process for arranging and filing of the } \\
\text { recorded documents into categories. } \\
\text { 2. Establish set of adaptive management models of control operations with the assistance of information } \\
\text { management systems to make operating personnel implement the practical operation exactly, thus improving } \\
\text { the efficiency and quality of the operation. } \\
\text { 3. Serve as a reference platform of learning knowledge required during employing new staff for their basic } \\
\text { instruction or during transferring between posts. }\end{array}$ \\
\hline
\end{tabular}

\section{Table 2. Worksheet OM-2.}

\begin{tabular}{|c|c|}
\hline \multicolumn{2}{|c|}{$\begin{array}{l}\text { Organization Model } \\
\text { Variant Aspects Worksheet OM-2 }\end{array}$} \\
\hline Structure & $\begin{array}{l}\text { The departure controlling operation involves several service groups containing the aviation weather center, } \\
\text { navigation information center and control tower, as shown in Figure } 2 \text {. Each group shall be controlled by the } \\
\text { high-level cadre that is designated. }\end{array}$ \\
\hline Process & $\begin{array}{l}\text { Figure } 3 \text { shows the diagram of departure controlling activity and shows that the activity can be subdivided into } \\
\text { the work of the application for a flight plan, control procedures of sliding and activities on the ground, } \\
\text { designation and verification of the flight level and the departure working procedures. }\end{array}$ \\
\hline People & All controllers \\
\hline Resources & Radar, radio and instrumental flight copying appliances relating to controlling. \\
\hline Knowledge & $\begin{array}{l}\text { The field of each department and its operating personnel and the knowledge and experiences of the technician } \\
\text { and control operating personnel are all significant knowledge assets of the control operation }\end{array}$ \\
\hline $\begin{array}{l}\text { Culture and } \\
\text { Power }\end{array}$ & $\begin{array}{l}\text { Most of the control operations are managed manually. It is difficult to share the quality, habitual experiences } \\
\text { and methods of educational training. The capabilities of coordinating integration are lacking between } \\
\text { departments when different departments need to coordinate with each other due to differences in work. }\end{array}$ \\
\hline
\end{tabular}

\section{Knowledge asset working sheet OM-4}

It is required to describe the knowledge asset applied in the problem under the knowledge asset of OM-3, which will serve as a basis for future improvements and will judge whether they are correct. Table 4 shows a working model sheet for OM-4.

Feasible decision working sheet $\mathrm{OM}-5$

It is required to propose solutions for a feasibility analysis of knowledge and technical support and for a feasibility analysis of a project based on the possible solutions proposed in OM-1 (Table 5).

\subsection{Establishment of Communications Model (CM)}

This research uses a UML sequence diagram to explain the relation of the main executing agent/related par- 
Table 3. Worksheet OM-3.

\begin{tabular}{|c|c|c|c|c|c|}
\hline \multicolumn{6}{|c|}{$\begin{array}{l}\text { Organization Model } \\
\text { Process Breakdown Worksheet OM-3 }\end{array}$} \\
\hline No. & Task & Performed by & Where? & Knowledge Asset & Significance \\
\hline 1 & $\begin{array}{l}\text { Work of } \\
\text { application for } \\
\text { flight plan }\end{array}$ & $\begin{array}{l}\text { Aircraft pilot, Flight Information } \\
\text { Center, } \\
\text { Area Control Center, Flight Data Center }\end{array}$ & $\begin{array}{l}\text { Aviation information } \\
\text { center, control tower } \\
\text { and meteorological } \\
\text { center }\end{array}$ & $\begin{array}{l}\text { Input airline and } \\
\text { terminal data }\end{array}$ & High \\
\hline 2 & $\begin{array}{l}\text { Control } \\
\text { procedure of } \\
\text { sliding and } \\
\text { activities on } \\
\text { ground }\end{array}$ & $\begin{array}{l}\text { Ground control seat, Area Control } \\
\text { Center, Aircraft Pilots }\end{array}$ & Control tower & $\begin{array}{l}\text { Provisions on ground } \\
\text { controlling operation, } \\
\text { selection of runway and } \\
\text { navigational status on } \\
\text { the ground, Precision } \\
\text { Approach }\end{array}$ & High \\
\hline 3 & $\begin{array}{l}\text { Designation and } \\
\text { verification of the } \\
\text { flight level }\end{array}$ & $\begin{array}{l}\text { Ground control, aircraft pilot, } \\
\text { Aerodrome control tower }\end{array}$ & Control tower & $\begin{array}{l}\text { Standard isolation } \\
\text { operation, airline } \\
\text { standard and } \\
\text { designation of the flight } \\
\text { level }\end{array}$ & High \\
\hline 4 & $\begin{array}{l}\text { Application for } \\
\text { departure } \\
\text { operation }\end{array}$ & $\begin{array}{l}\text { Area Control Center, aircraft pilot, } \\
\text { Aerodrome control tower, Ground } \\
\text { Control }\end{array}$ & $\begin{array}{l}\text { Control tower and } \\
\text { aviation information } \\
\text { center }\end{array}$ & $\begin{array}{l}\text { Interval and sequence, } \\
\text { airport conditions, } \\
\text { aerodrome lights and } \\
\text { clearance }\end{array}$ & High \\
\hline
\end{tabular}

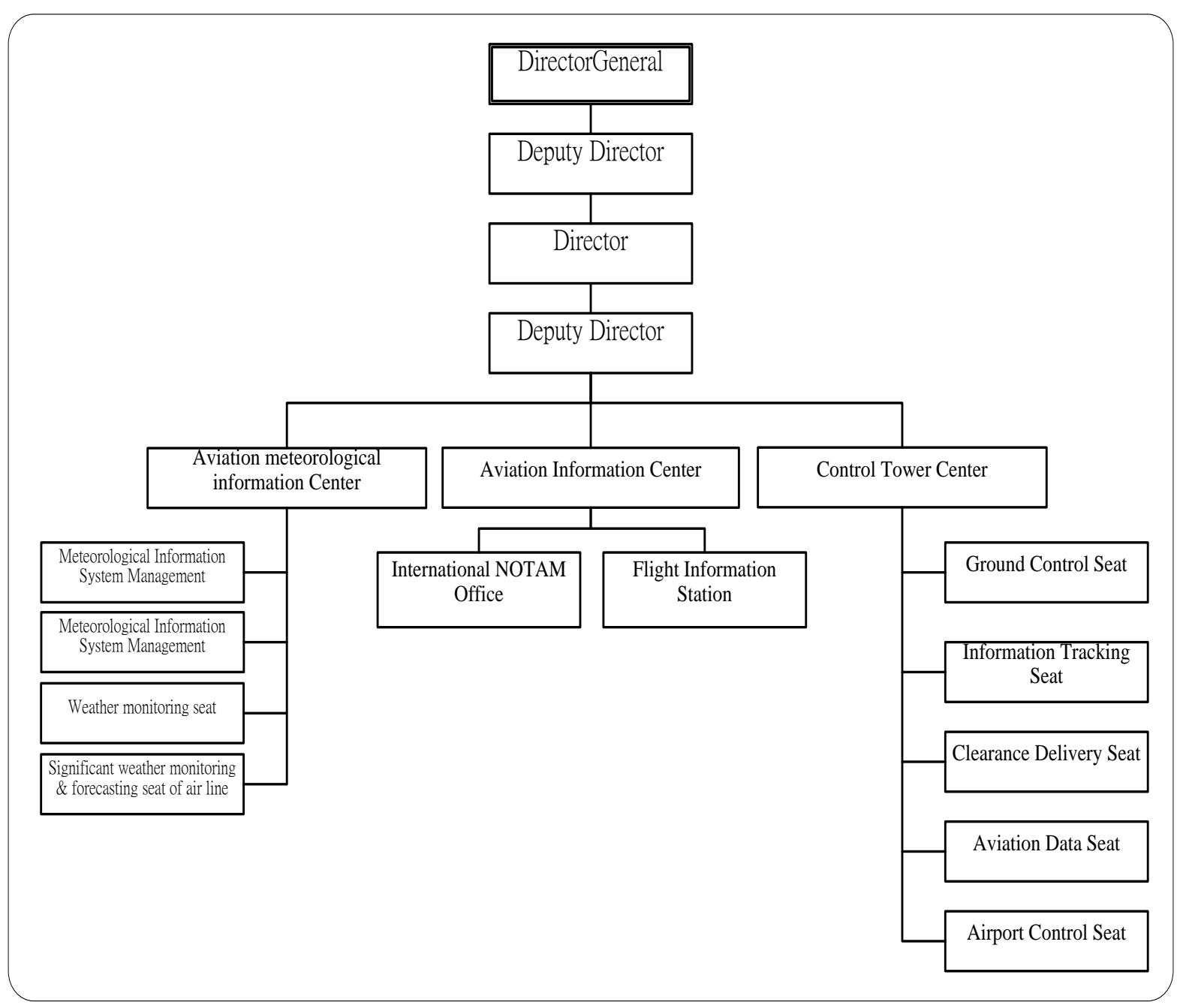

Figure 2. Organization framework diagram of the aviation information center. 


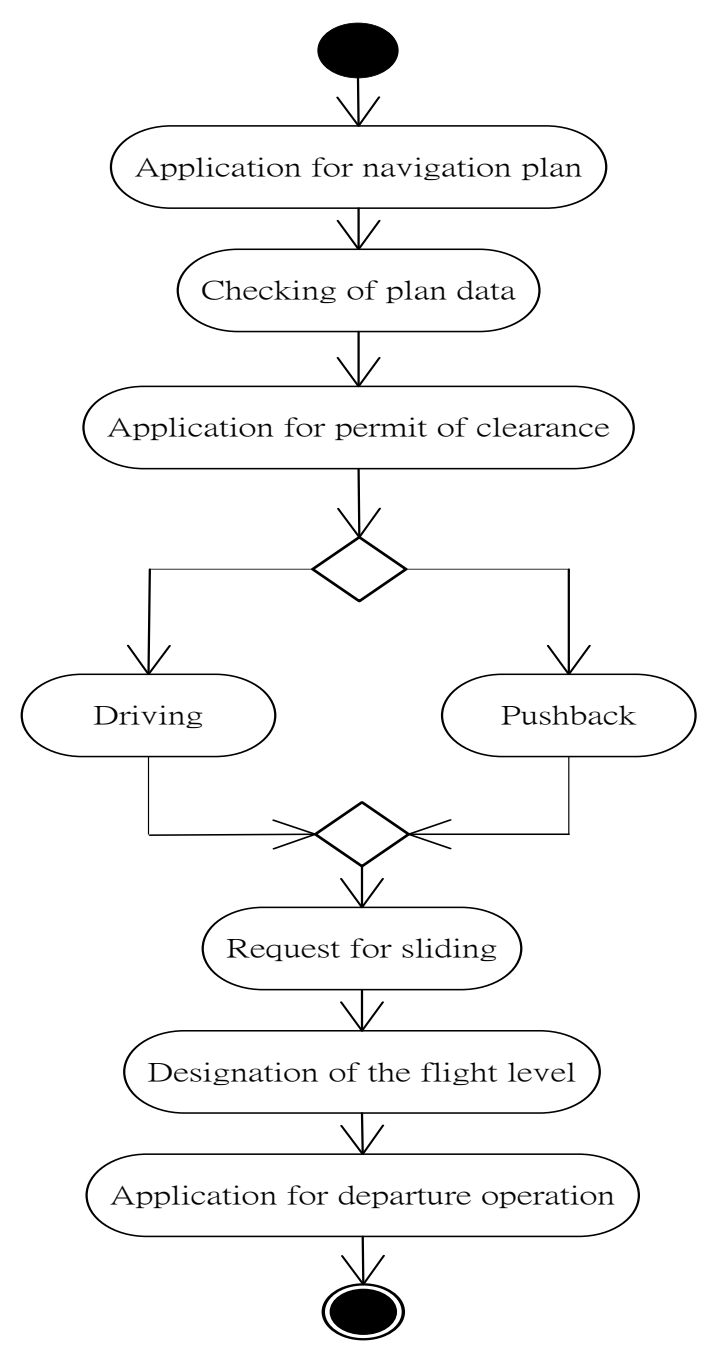

Figure 3. Control activity diagram.

ticipating agents and the authorization process. The overall communication plan can be described in a single diagram. Figure 4 shows the main states and transitions involved in this task.

\subsection{System Implementation}

This study transformed tacit knowledge to explicit knowledge with CommonKADS models and steps. Then, based on the constructed knowledge models, this study established domain ontology and knowledge management models using the Protégé tool as the following:

1) Define the concepts (class, set, and concept): Establish the ontology set or conception.

2) Establish properties (slot, property, role and relation): Define the relation or property of each class. In this task, this research adds the departure procedures and system documents, allowing the domain knowledge and the system documentation to be combined with this prototype.

3) Establish entity (instance, object, and individual): Establish the entity for each class and relation.

Construction result: According to Figure 5, it can be obviously seen that the class of card checkup includes three slots: Work of Application for a Flight Plan, Control Procedure Program of Sliding and Activities on Ground, Designation and Verification of Flight Level, and Departure Operation Application, comprising four instances. Check the contents of this class by monitoring the instance. Figure 6 shows that there are nine checkup items (Telegraphic codes) during Route Information, supported by system document, which is a specification coded by the Telegraphic code description. Through the simple and user-friendly interface of Protégé, 
Table 4. Worksheet OM-4.

\begin{tabular}{|c|c|c|c|c|}
\hline \multicolumn{5}{|c|}{$\begin{array}{l}\text { Organization Model } \\
\text { Knowledge Assets Worksheet OM-4 }\end{array}$} \\
\hline Knowledge Asset & Possessed by & Used in & $\begin{array}{l}\text { Right } \\
\text { Form }\end{array}$ & $\begin{array}{l}\text { Right } \\
\text { Place }\end{array}$ \\
\hline Input airline & Aircraft Pilots, Flight Information Center & Application for flight plan & $\mathrm{Y}$ & $\mathrm{Y}$ \\
\hline Terminal data & $\begin{array}{l}\text { Area Control Center, Flight Information } \\
\text { Center, Area Control Center }\end{array}$ & Application for flight plan & $\mathrm{Y}$ & $\mathrm{Y}$ \\
\hline Instrument Flight Rules & Flight Data Center & Application for flight plan & $\mathrm{Y}$ & $\mathrm{Y}$ \\
\hline Visual Flight Rules & Area Control Center & Application for flight plan & $\mathrm{Y}$ & $\mathrm{Y}$ \\
\hline $\begin{array}{l}\text { Provisions on ground controlling } \\
\text { operation }\end{array}$ & Ground control seat & $\begin{array}{l}\text { Control sliding and } \\
\text { activities on ground }\end{array}$ & $\mathrm{Y}$ & $\mathrm{Y}$ \\
\hline $\begin{array}{l}\text { Selection of runway and } \\
\text { navigational status on the ground }\end{array}$ & Ground control seat & $\begin{array}{l}\text { Control sliding and } \\
\text { activities on ground }\end{array}$ & $\mathrm{Y}$ & $\mathrm{Y}$ \\
\hline Precision Approach & Ground control seat, Aircraft Pilots & $\begin{array}{l}\text { Control sliding and } \\
\text { activities on ground }\end{array}$ & $\mathrm{Y}$ & $\mathrm{Y}$ \\
\hline Standard isolation operation & Ground control Aerodrome control tower & $\begin{array}{l}\text { Designation and } \\
\text { verification of the flight level }\end{array}$ & $\mathrm{Y}$ & $\mathrm{Y}$ \\
\hline Airline standard & Ground control Aerodrome control tower & $\begin{array}{l}\text { Designation and verification } \\
\text { of the flight level }\end{array}$ & $\mathrm{Y}$ & $\mathrm{Y}$ \\
\hline Designation of the flight level & Aerodrome control tower & $\begin{array}{l}\text { Designation and verification } \\
\text { of the flight level }\end{array}$ & $\mathrm{Y}$ & $\mathrm{Y}$ \\
\hline Interval and sequence & Aerodrome control tower & $\begin{array}{l}\text { Application for departure } \\
\text { operation }\end{array}$ & $\mathrm{Y}$ & $\mathrm{Y}$ \\
\hline Airport conditions & Aerodrome control tower & $\begin{array}{l}\text { Application for departure } \\
\text { operation }\end{array}$ & $\mathrm{Y}$ & $\mathrm{Y}$ \\
\hline Aerodrome lights & Ground Controlled & $\begin{array}{l}\text { Application for departure } \\
\text { operation }\end{array}$ & $\mathrm{Y}$ & $\mathrm{Y}$ \\
\hline Clearance & $\begin{array}{l}\text { Area Control Center, Aerodrome control } \\
\text { tower }\end{array}$ & $\begin{array}{l}\text { Application for departure } \\
\text { operation }\end{array}$ & $\mathrm{Y}$ & $\mathrm{Y}$ \\
\hline
\end{tabular}

Table 5. Worksheet OM-5.

\begin{tabular}{|c|c|}
\hline \multicolumn{2}{|c|}{$\begin{array}{l}\text { Organization Model } \\
\text { Checklist for Feasibility Decision Document: Worksheet OM-5 }\end{array}$} \\
\hline $\begin{array}{l}\text { Organization } \\
\text { Model }\end{array}$ & Feasible decision working sheet OM-5 \\
\hline Feasibility & $\begin{array}{l}\text { Evaluate and confirm the resources and knowledge assets of the experts and aviation management } \\
\text { procedures. Effectively inherit practical techniques and experience, which can be the knowledge } \\
\text { learning platform required during employing new staff for the basic layer of education or for post } \\
\text { transferring and the important evidence for policy-making in the case of an emergency crisis. }\end{array}$ \\
\hline \multirow[t]{2}{*}{$\begin{array}{l}\text { Technical } \\
\text { Feasibility }\end{array}$} & $\begin{array}{l}\text { The applications of developed information technology, an information base and the internet are very } \\
\text { popular now, and various types of tools supporting knowledge management activity are becoming } \\
\text { increasingly advanced. These tools are technologically supportive to each other. By establishing a } \\
\text { knowledge management platform, the time for personnel training is reduced and their work quality is } \\
\text { promoted. }\end{array}$ \\
\hline & $\begin{array}{l}\text { Integrate the control operation document to avoid repetition of the relevant knowledge and to avoid a } \\
\text { waste of searching time, thus improving the efficiency of learning the control operation. } \\
\text { All tools and methodologies are mature: }\end{array}$ \\
\hline Project & .NET, JAVA, Protégé, UML \\
\hline \multirow[t]{2}{*}{ Feasibility } & $\begin{array}{l}\text { Object-Oriented Programming: } \\
\text {.NET, JAVA, Protégé, UML } \\
\text { Methodology: } \\
\text { CommonKADS, Ontology }\end{array}$ \\
\hline & $\begin{array}{l}\text { 1. Effectively establish information technology. Establish a complete and exact knowledge network } \\
\text { and knowledge base system. Appropriately adjust the relevant control operation procedures and } \\
\text { terminologies relating to the control operations. }\end{array}$ \\
\hline \multirow[t]{2}{*}{$\begin{array}{l}\text { Proposed } \\
\text { Actions }\end{array}$} & $\begin{array}{l}\text { 2. Document and use electronics systems in the operation process and records to ease the transmission } \\
\text { and sharing of knowledge. }\end{array}$ \\
\hline & $\begin{array}{l}\text { 3. Construct a new mode for establishing the platform of departure control operations knowledge } \\
\text { without making the establishment and management of the system a burden to personnel; present a } \\
\text { complete layout of the departure control operation knowledge. }\end{array}$ \\
\hline
\end{tabular}




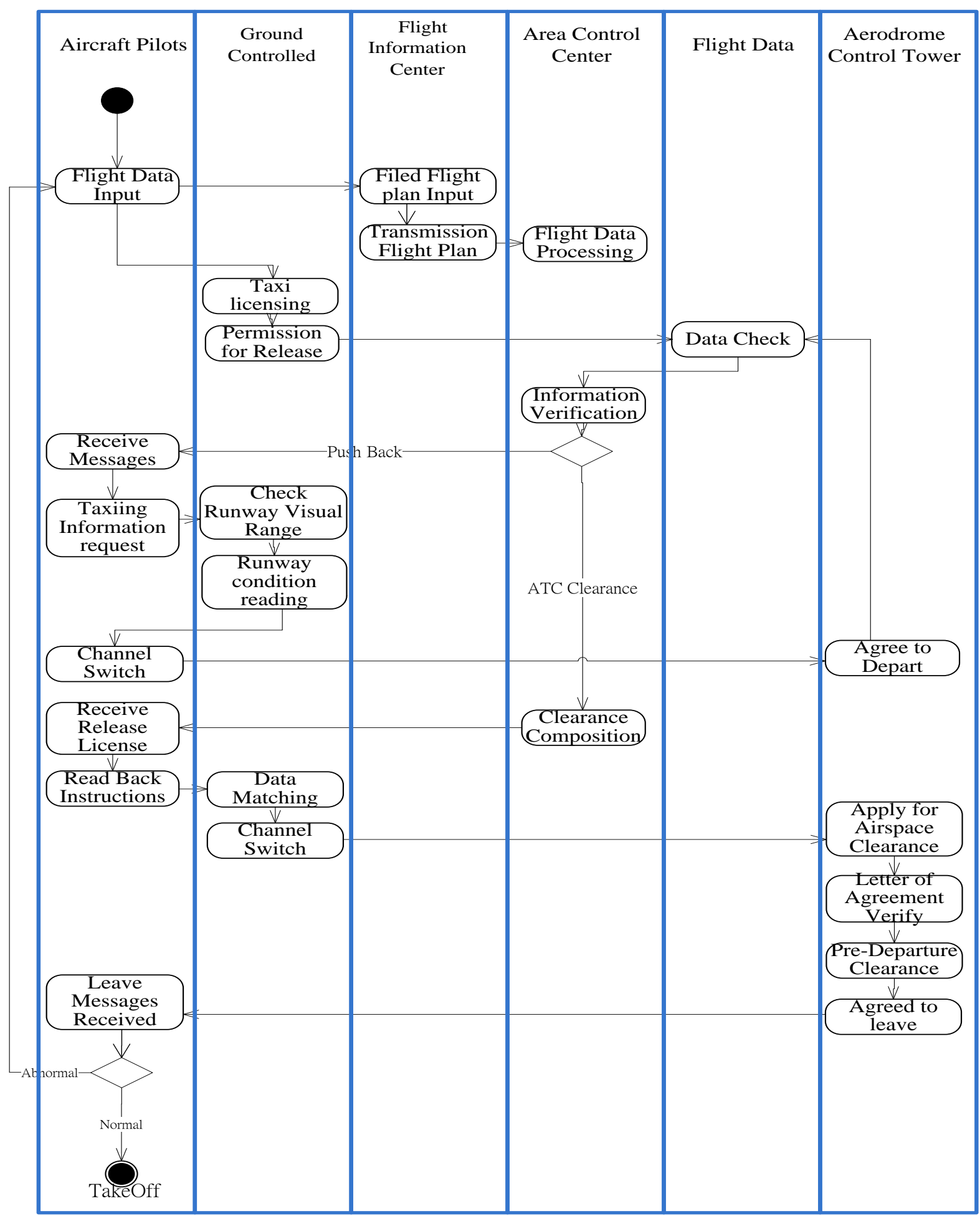

Figure 4. Communications model.

this study could obtain the relevant procedure and system documents of all types in addition to concepts and information.

\section{Case Description}

On August 6th, 1998, because the safeguard safety, engineering supervising, navigation control and control 


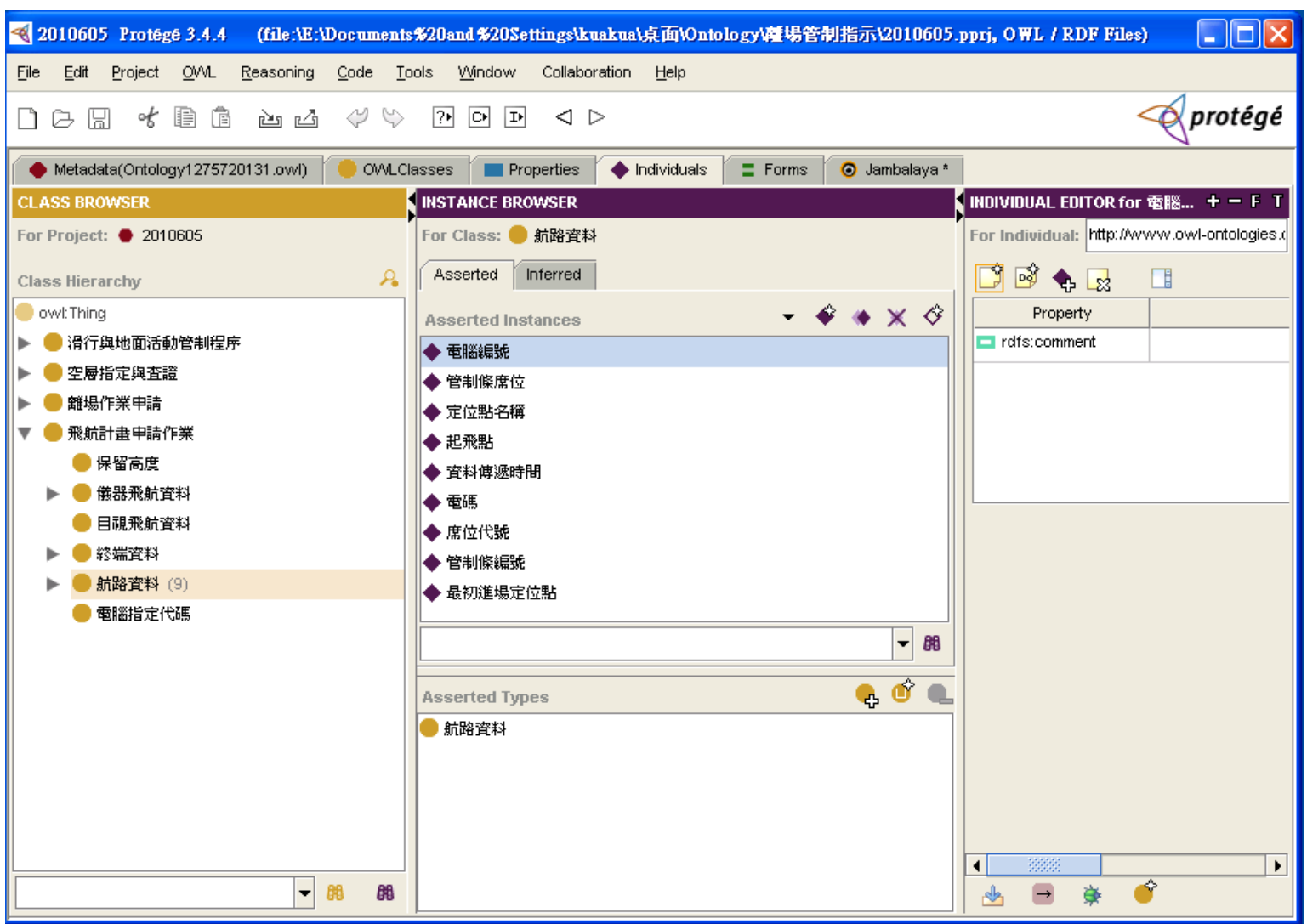

Figure 5. Departure procedures knowledge establishment results 1.

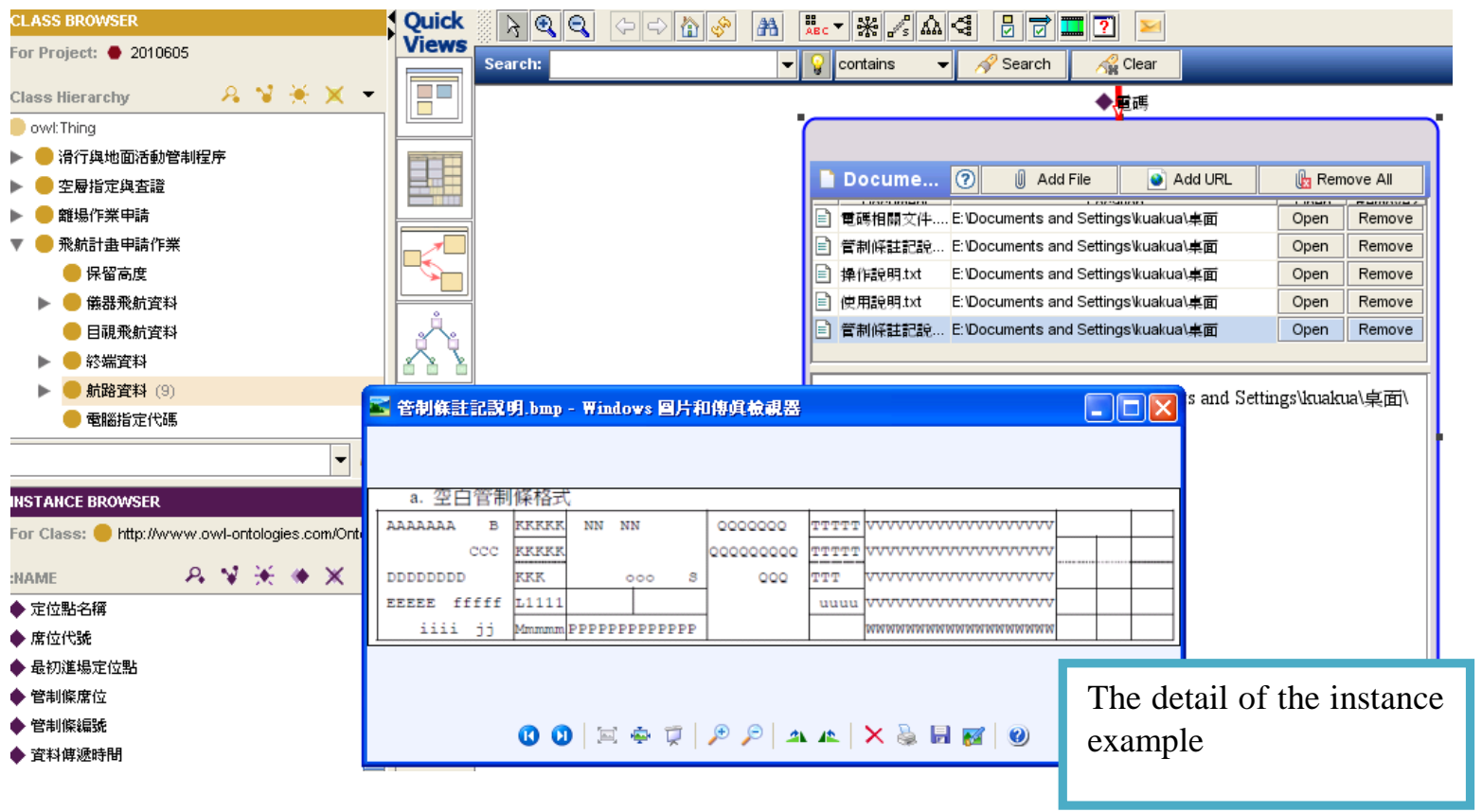

Figure 6. Departure procedures knowledge establishment results 2.

tower navigation management in Tainan Base under the jurisdiction of Air Force 443 wing were too rash and insufficient during their work, relevant airport training and aircraft separation were insufficient. This deficiency 
resulted in the crash of aircraft from the Transasia Airways Company with a construction vehicle on the track when it landed at Tainan Airport. This accident seriously damaged the navigation safety of the airport for both military and civilian use as well as affecting its military image. With the description of this case, the research considers the vertical separation as the crucial factor for the accident and deduces the most suitable information and relevant operation process to provide the best real-time services through the Knowledge Management Model established in this study.

Step 1: After control operation personnel selects to search longitudinal distance, the system will automatically display the knowledge association of activities relating to the involved departure control operation on the picture in blue bold letters, as shown in Figure 7.

Step 2: According to the lowest standard shown in the picture, control operation personnel determine whether the current flight level of the aircraft is above 410, above 290 or below 410, as shown in boldface arrows of Figure 8.

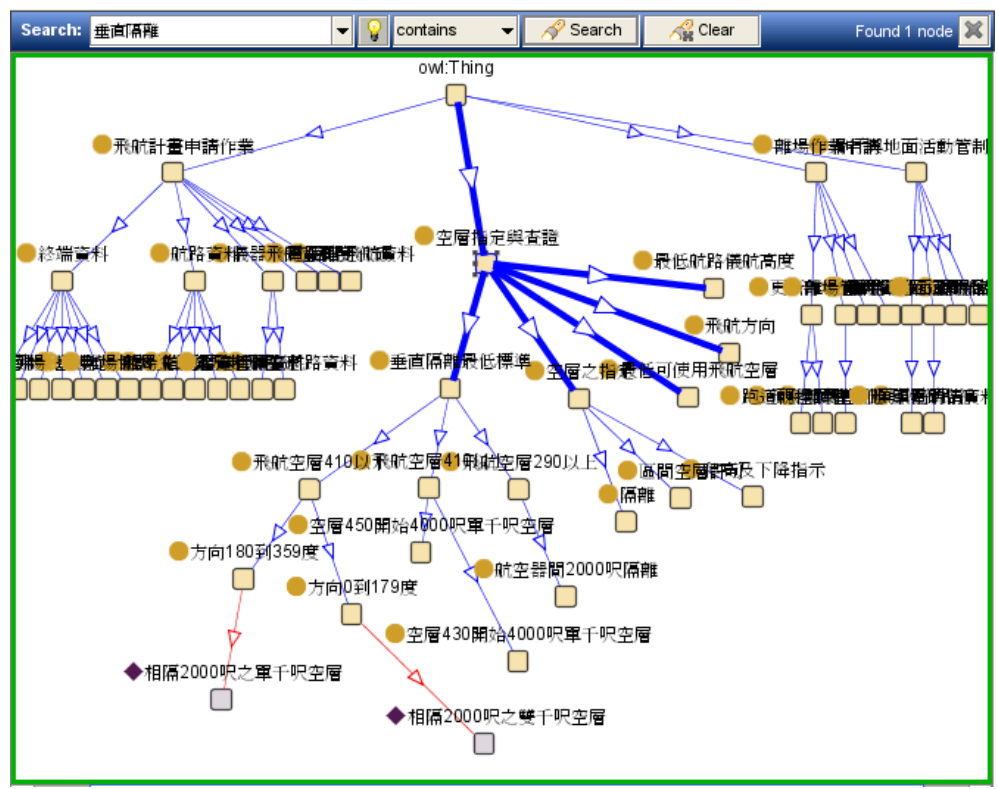

Figure 7. Vertical separation control association.

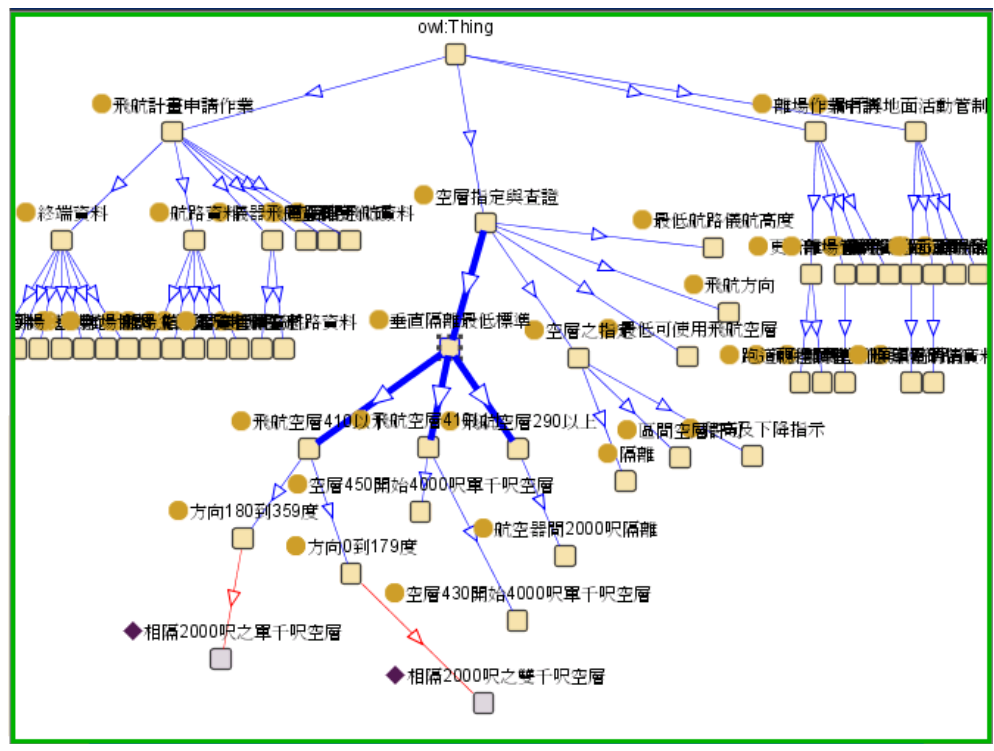

Figure 8. Vertical separation association of flight level determination. 
Step 3: After determining the current flight level of the aircraft, control personnel may determine whether the navigation direction of the aircraft is $180^{\circ}-359^{\circ}$ or $0^{\circ}-179^{\circ}$ and may choose to review separation example instructions and related separation standard operations documents. With the knowledge model established in this research, control personnel can quickly find the information needed in control operations and thus improve control efficiency, as shown in Figure 9.

In this paragraph, CommonKADS theory will be followed with a combination of expert knowledge, navigation management procedures and information systems to establish the Organization Model, Task Model, Agent Model, Knowledge Model and Communication Model and to display current departure operations. With the help of the Knowledge Model established in this research and by using Protégé as a tool, a set of knowledge management models will be built; the OWL establishment Domain Ontology generated by the model will be used as a knowledge sharing tool, and through the extended function of Plugins, the information will be displayed in graphs. Departure control operations and system establishment procedures will be perfectly displayed, and a framework and function model in complete accordance with current navigation systems will be built to complete the knowledge capture process and the transformation from Tacit Knowledge into Explicit Knowledge.

\section{Conclusions}

\subsection{Implications}

According to the data provided by Executive Yuan of the Aviation Safety Council, the volume of air navigation has been multiplying each year because of the prosperity of the aviation industry, which results in the increase in the air traffic controllers' daily work load. Decision-making capacity is the key to processing a flight safety crisis. An improper or too slow of a decision always leads to an irreparable situation. Thus, flight safety will be improved if the procedures and knowledge of operating standards can be effectively improved and if the process

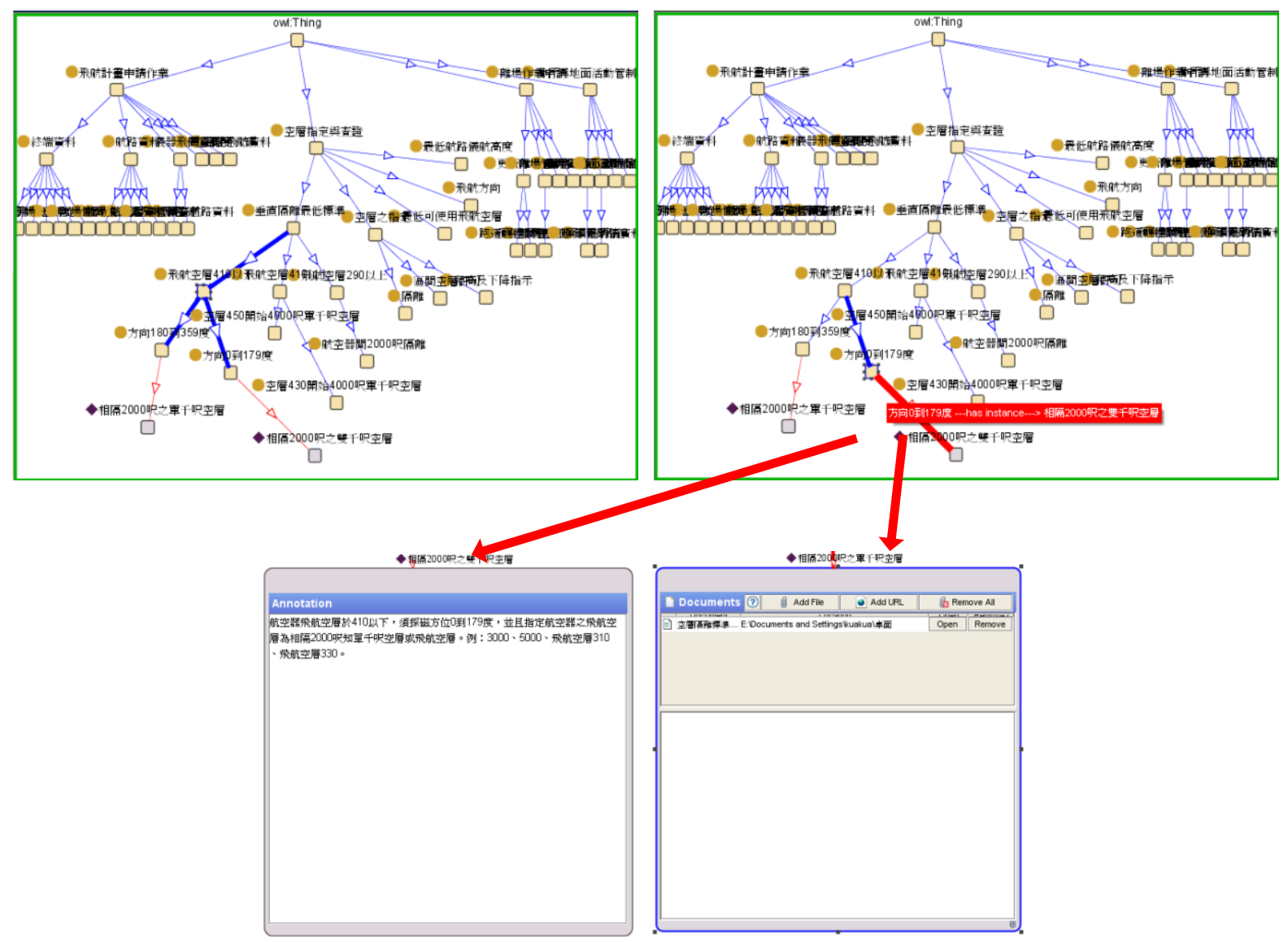

Figure 9. Vertical separation association of the flight level determination operation. 
of unsatisfactory situations can be identified and improved. The process of upgrading the training materials to enable air traffic controllers to quickly make good judgments will be a significant task.

This study analyzed and established knowledge models for the professional knowledge contained in departure procedures and transformed the tacit knowledge in domain experts to explicit knowledge. In addition, this study uses the OWL and UML languages to accomplish the data analysis and storage so that the knowledge can be more effectively managed, shared, and used. The academic contributions of this study are as follows:

- The traditional method to retrieve information is to use the Air Traffic Management Procedures books and the Civil Aviation Authority website. However, this study develops a knowledge model that can aid traditional methods for retrieving aviation law and regulations accurately and efficiently. The model can not only be used as a learning platform for Control operations personnel but also can be used to compare the system structure. Thus, in the case of a system alteration, this study could quickly identify the degree of alteration and the range of influence and reduce communication between business personnel.

- In the framework of the CommonKADS methodology, attention is given to the organizational consequences that knowledge-based systems can have [25]. In previous studies, the organizational model has been used in biotechnology and has been applied to military education and training in several projects. These applications are of particular importance in this research, especially in the application considered here, in which the task model will form a part of a much larger process involving many separate participants. By disassembling the departure procedure and the professional knowledge contained in each stage to make knowledge maps, the personnel who require professional knowledge can find the best resolution within the shortest time.

\subsection{Limitations and Future Work}

This study focuses on the analysis of the departure control procedure without any analysis of the other operations. Researchers can only use limited resources, a single operational procedure and the most appropriate methodology to discuss the knowledge system for the operational nodes. If the procedure constructed in this paper is effective, then other operations can refer to it to build their own knowledge systems in the future. When all individual knowledge systems of the operations in the ATC field have been constructed, this study could conduct horizontal connections to finish the construction of the entire knowledge field. There is still plenty of room for improvement and further in-depth study. Therefore, recommendations are made to offer discussion topics and directions for future researchers.

This study has studied how explicit knowledge is transformed by CommonKADS methodology using the CommonKADS sheet, and the UML graph presentation and ontology model are discussed in this research. The analysis procedure can be applied to the systematic analysis and establishment of similar knowledge-based systems, allowing this research result to be further shared in different industries.

This study has established the Organization model, Agent model, Knowledge model and Communication model. Future researchers can directly establish the design model and can complete the overall development of the knowledge-based system.

\section{References}

[1] Edwards, E. (1972) Man and Machine: Systems for Safety. Proceedings of British Airline Pilots Association Technical Symposium, British Airline Pilots Association, London, 21-36.

[2] Chang, Y.H. and Yeh, C.H. (2009) Human Performance Interfaces in Air Traffic Control. Applied Ergonomics, 41, 123-129. http://dx.doi.org/10.1016/j.apergo.2009.06.002

[3] Hawkins, F.H. (1987) Human Factors in Flight. Gower Technical Press, Aldershot.

[4] Galster, S.M., Duley, J.A., Masalonis, A.J. and Parasuraman, R. (2001) Air Traffic Controller Performance and Workload under Mature Free Flight: Conflict Detection and Resolution of Aircraft Selfseparation. The International Journal of Aviation Psychology, 11, 71-93. http://dx.doi.org/10.1207/S15327108IJAP1101_5

[5] Salden, R.J.C.M., Paas, F., Jeroen, J.G. and Merriënboer, V. (2006) Personalised Adaptive Task Selection in Air Traffic Control: Effects on Training Efficiency and Transfer. Learning and Instruction, 16, 350-362. http://dx.doi.org/10.1016/j.learninstruc.2006.07.007

[6] Su, K.W., Wang, H.Y., Li, K.J., Wang, C.H. and Hsiao, P.H. (2011) Designing and Evaluating an Ontology-Based Air Traffic Control Digital Knowledge Learning System. User Science and Engineering (i-USEr), 172-177.

[7] Lowe, C.E., Cooper, J.D., Chapman, J.M., Barrant, B.J., Twells, R.C.J., Green, E.A., Savage, D.A., Guja, C., Iones- 
cu-Tîrovişte, C., Tuomilehto-Wolf, E., Tuomilehto, J., Todd, J.A. and Clayton, D.G. (2005) Cost-Effective Analysis of Candidate Genes Using htSNPs: A Staged Approach. Genes \& Immunity, 5, 301-305. http://dx.doi.org/10.1038/sj.gene.6364064

[8] Boeing Airplane Company (2005) Statistical Summary of Commercial Jet Airplane Accidents 1959-2006. Boeing Commercial Airplane Group, Seattle.

[9] Wilson, L. and Asay, D. (1999) Putting Quality in Knowledge Management. Quality Progress, 32, 25-31.

[10] Zollo, M. and Winter, S.G. (2002) Deliberate Learning and the Evolution of Dynamic Capability. Organization Science, 13, 339-352. http://dx.doi.org/10.1287/orsc.13.3.339.2780

[11] Davenport, T.H. and Prusak, L. (1998) Working Knowledge. Harvard Business School Press, Boston.

[12] Boisot, M.H. (1998) Knowledge Assets. Oxford University Press, Oxford.

[13] Pentland, B.T. (1995) Information Systems and Organizational Learning: The Social Epistemology of Organizational Knowledge Systems. Accounting, Management and Information Technologies, 5, 1-21. http://dx.doi.org/10.1016/0959-8022(95)90011-X

[14] Akkermans, H., Schreiber, G., Anjewierden, A., de Hoog, R., Shadbolt, N., de Velde, W.V. and Wielinga, B. (1999) Knowledge Engineering and Management: The CommonKADS Methodology. MIT Press, Cambridge.

[15] Ying, D. (2005) Ontology: The Enabler for the Semantic Web. Division of Mathematics and Computer Science, Free University, Amsterdam.

[16] Tan, J. and Poslad, S. (2004) Dynamic Security Reconfiguration for the Semantic Web. Autonomic Computing Systems, 17, 783-797. http://dx.doi.org/10.1016/s0952-1976(04)00118-6

[17] Sugumaran, V. and Storey, V.C. (2002) Ontologies for Conceptual Modeling: Their Reation, Use, and Management. Data \& Knowledge Engineering, 42, 251-271. http://dx.doi.org/10.1016/S0169-023X(02)00048-4

[18] Chandrasekaran, B., Josephson, J.R. and Benjamins, V.R. (1999) What Are Ontologies, and Why Do We Need Them? IEEE Intelligent Systems and Their Applications, 14, 20-26. http://dx.doi.org/10.1109/5254.747902

[19] Sergey, S. and Tatiana, G. (2006) Development of Educational Ontology for C-Programming. International Journal on Information Theories \& Applications, 13, 303-308.

[20] McGuinness, D.L. and Harmelen, F.V. (2004) OWL Web Ontology Language Overview. http://www.w3.org/TR/2004/REC-owl-features-20040210/

[21] Huang, N. and Diao, S. (2008) Ontology-Based Enterprise Knowledge Integration. Third International Conference on Manufacturing Research, Robotics and Computer-Integrated Manufacturing, 24, 562-571. http://dx.doi.org/10.1016/j.rcim.2007.07.007

[22] Oscar, C., Mariano, F.-L. and Asuncion, G.-P. (2003) Methodologies, Tools and Languages for Building Ontologies. Where Is Their Meeting Point? Data \& Knowledge Engineering, 46, 41-64. http://dx.doi.org/10.1016/S0169-023X(02)00195-7

[23] Satish, M. (2008) Visual Modeling and Unified Modeling Language (UML): Introduction to UML. Rational Software Corporation.

[24] Booch, G., Rumbaugh, J. and Jacobson, I. (1998) The Unified Modeling Language Users Guide. Addison-Wesley Professional.

[25] HoogR. D., Benus, B., Vogler, M. and Metselaar, C. (1996) The CommonKADS Organization Model: Content, Usage and Computer Support. Expert Systems with Applications, 11, 29-40. http://dx.doi.org/10.1016/0957-4174(96)00003-6 


\section{Submit or recommend next manuscript to SCIRP and we will provide best service for you:}

Accepting pre-submission inquiries through Email, Facebook, Linkedin, Twitter, etc A wide selection of journals (inclusive of 9 subjects, more than 200 journals)

Providing a 24-hour high-quality service

User-friendly online submission system

Fair and swift peer-review system

Efficient typesetting and proofreading procedure

Display of the result of downloads and visits, as well as the number of cited articles

Maximum dissemination of your research work

Submit your manuscript at: http://papersubmission.scirp.org/ 